\title{
Endometrial CD56+ natural killer cells in women with recurrent implantation failure: An immunohistochemical study
}

\section{Tekrarlayan implantasyon başarısızlıklarında endometriyal CD56+ natürel killer hücreleri: İmmünohistokimyasal çalışma}

\author{
(1) Gulchin Babayeva ${ }^{1}$, (1) Yunus Emre Purut ${ }^{2}$, (1) Burak Giray ${ }^{2}$, (1) Pembe Oltulu ${ }^{3}$, (1) Rabia Alakuş ${ }^{3}$, \\ (1) Mehmet Cengiz Çolakoğlul \\ ${ }^{1}$ Necmettin Erbakan University Meram Faculty of Medicine, Department of Obstetrics and Gynecology, Konya, Turkey \\ 2Zeynep Kamil Women and Children Diseases Training and Research Hospital, Clinic of Obstetrics and Gynecology, İstanbul, Turkey \\ ${ }^{3}$ Necmettin Erbakan University Meram Faculty of Medicine, Department of Pathology, Konya, Turkey
}

\begin{abstract}
Objective: Implantation failure is a multifactorial problem of reproductive medicine. However, the mechanism of this process is still not fully understood. There is increasing evidence that these cases of recurrent implantation failure might have an immunologic background. Uterine natural killer (NK) cells provide immune-modulation at the interface between maternal decidua and the trophoblast. The aim of this study to evaluate whether there was a significant difference in the number of endometrial CD56+ NK between women with a history of recurrent implantation failure and women who had a live birth.

Materials and Methods: Patients with a history of recurrent implantation failure were included in the study. Twenty-five women with a history of recurrent implantation failure were assigned to the case group, and 25 women who had one or more live births were assigned to the control group. Endometrial biopsies were obtained during the luteal phase on the $21^{\text {st }}-24^{\text {th }}$ day of the menstrual cycle.

Results: There was a statistically significant difference between the groups concerning the number of deliveries $(\mathrm{p}<0.001)$ and miscarriages $(\mathrm{p}<0.001)$. The mean number of uNK was $10.5 \pm 10.5$ cells $/ \mathrm{mm}^{2}$ in the case group and $19.2 \pm 11.2 \mathrm{cells} / \mathrm{mm}^{2}$ in the control group. There was a statistically significant difference between the two groups ( $\mathrm{p}=0.003$ ).

Conclusion: Implantation failure is a multifactorial problem of reproductive medicine. The results of our study suggest that uterine NK play a role in the progress of normal pregnancy and reduced uterine NK cell numbers were associated with implantation failure.

Keywords: CD56, immunohistochemistry, in vitro fertilization, recurrent implantation failure, uterine natural killer cells

Öz

Amaç: İmplantasyon başarısızlıkları reprodüktif tıbbın multifaktöriyel bir problemidir. Tam mekanizması günümüzde halen aydınlatılamamıştır. Son ylllarda mekanizmasında immünolojik faktörlerin etkili olduğuna dair kanıtlar artmaktadır. Uterin natürel killer (uNK) hücreleri trofoblastlar ile desidua arasında immün modülasyonu sağlar. Çalışmamızın amacı tekrarlayan implantasyon başarısızlığı olan olgular ile canlı doğuma sahip olan kadınlar arasında uNK hücreleri açısından fark olup olmadığının araştırılmasıdır.

Gereç ve Yöntemler: Çalışmaya tekrarlayan implantasyon başarısızlı̆̆ı olan hastalar dahil edildi. Yirmi beş implantasyon başarısızlığı olan hasta olgu grubunu, 25 canlı doğum öyküsü olan kadın ise kontrol grubunu olușturdu. Endometriyal biyopsiler menstruel döngünün 21. ile 24. günleri arasında luteal fazda alındı. Her iki grup uNK açısından karşılaştıııldı.

Bulgular: Her iki grup arasında canlı doğum $(\mathrm{p}<0,001)$ ve düşük sayısı $(\mathrm{p}<0,001)$ açısından anlamlı fark vardı. Olgu grubunda ortalama uNK sayısı $10,5 \pm 10,5$ cells $/ \mathrm{mm}^{2}$ idi. Kontrol grubunda ise 19,2 $\pm 11,2$ cell $/ \mathrm{mm}^{2}$ idi. Olgu grubunda uNK sayısı anlamlı olarak daha az olarak bulundu ( $\mathrm{p}=0,003$ ).

Sonuç: İmplantasyon başarısızlıkları reprodüktif tıbbın multifaktöriyel bir problemidir. Çalışmamızda uNK hücrelerinin gebeliğin devamında önemli bir rol oynadığı ve sayılarının azalmasının tekrarlayan implantasyon başarısızlığıyla ilişkili olduğu bulunmuştur.

Anahtar Kelimeler: CD56, immünohistokimya, in vitro fertilizasyon, tekrarlayan implantasyon başarısızlı̆̆ı, uterin naturel killer hücreleri
\end{abstract}

PRECIS: We evaluated whether there was an effect of the number of endometrial CD56+ NK on women with a history of recurrent implantation failure.

Address for Correspondence/Yazışma Adresi: Gulchin Babayeva MD,

Necmettin Erbakan University Meram Faculty of Medicine, Department of Obstetrics and Gynecology, Konya, Turkey

Phone: +090 3322236000 E-mail: drgunuvar@gmail.com ORCID ID: orcid.org/0000-0003-1519-2255

Received/Gelis Tarihi: 24.09.2019 Accepted/Kabul Tarihi: 18.10.2020

${ }^{\oplus}$ Copyright 2020 by Turkish Society of Obstetrics and Gynecology

Turkish Journal of Obstetrics and Gynecology published by Galenos Publishing House 


\section{Introduction}

Accomplished implantation of an eight-cell embryo into the endometrium is mandatory for reproduction. The rate of successful implantation of an embryo is approximately $30 \%{ }^{(1)}$. Implantation failure is a multifactorial problem of reproductive medicine. Recurrent implantation failure (RIF) was defined as a failure of pregnancy after at least three previous assisted reproductive technique cycles, or implantation failure with a transfer of more than four embryos by the European Society of Human Reproduction and Embryology. A successful pregnancy requires synchronization between the trophoblasts and endometrium. However, the mechanism of this process is still not fully understood.

There is increasing evidence that these cases of RIF might have an immunologic background. The endometrium plays a role in implantation physiology via immune cells, cytokines, and chemokines ${ }^{(2)}$. Multiple kinds of immune cells are potentially involved in supporting immune tolerance during implantation and successful ongoing pregnancy ${ }^{(3)}$. Uterine natural killer (uNK) cells express their specific cell surface marker CD56, and differ from blood NK cells ${ }^{(4)}$. These uNK cells are the dominant leukocyte population (70-90\% of uterine lymphocytes) in the decidua at the time of implantation and early placentation ${ }^{(5)}$. Although the function of uNK cells is uncertain, the regulation of uNK cells at the time of eight-cell embryo implantation is thought to feature in implantation. In a normal pregnancy, uNK cells provide immune-modulation at the interface between decidual tissue and trophoblast. We aimed to evaluate whether there was a significant difference in the count of endometrial CD56+ NK between women with RIF and women who had a live birth.

\section{Materials and Methods}

\section{Participants and Study Design}

Twenty-five women with RIF and 25 women who had one or more live births between January 2012 and December 2017 were included in the study. RIF was defined as the failure of good quality embryos to implant after at least 3 cycles of IVF. Women with positive for anti-phospholipid antibodies (ANA, anticardiolipin IgM and IgG, anti-DNA, antiphospholipid IgM and $\operatorname{Ig} G$ ), anti-toxoplasma IgM, and/or anti-rubella IgM were excluded from the study. Women with abnormal thyroid function tests results, anti-thrombin III deficiency, protein C or $\mathrm{S}$ deficiency, factor-V-Leiden mutation, prothrombin gene mutation, mutation of MTHFR C677T gene, and/or mutation of MTHFR A1298C gene were also excluded from the study. Hysterosalpingography was performed in all infertile patients before the procedure and there were no abnormal findings. Twenty-five women who had one or more live births were assigned to the control group. None of the 25 women in the control group received assisted reproduction treatment at any time. The local ethics committee approved the study (approval no: 20181146). The patients were informed orally and in writing.

\section{Collection of Tissue Samples and Histopathologic Examination}

Endometrial biopsies were obtained during the luteal phase on the $21^{\mathrm{st}}-24^{\text {th }}$ day of the menstrual cycle using the Pipelle device and fixed in 10\% formaldehyde. Formalin-fixed and paraffin-embedded tissue samples were incubated for 120-minutes with the CD 56 primary antibody (NCL-L-CD561B6, 1/200 dilution, Novocastra Laboratories Ltd.), 30 minutes with biotin (Dako LSAB System-HRP, Dako North America, Inc., K0690), and 30 minutes with streptavidin (Dako LSAB System-HRP, Dako North America, Inc., K0690), respectively. Aminoethylcarbazole chromogen was added for 15 minutes. Paraffin-embedded tissue samples were stained using Mayer's hematoxylin. The same pathologist evaluated all samples using an Olympus BX53 microscope at 400x magnification. CD56+ cell counts were determined as cells $/ \mathrm{mm}^{2}$ (Figure 1).

\section{Statistical Analysis}

Data were analyzed using the SPSS software package (22.0, IBM SPSS Statistics for Windows; IBM Corp. Armonk, NY). Histogram, normality plots, and thre Shapiro-Wilk normality test were used to analyze data distribution. Descriptive statistics (mean, standard deviation, median, range, percentage) were used in the analysis of quantitative data. The chi-square $\left(\chi^{2}\right)$ test or Fisher's Exact test was used to analyze qualitative data. The Mann-Whitney $U$ test was used in the analysis of quantitative data. Statistical significance was established at $\mathrm{p}<0.05$.

\section{Results}

Twenty-five women with RIF and 25 women as fertile controls were included in the study. The parental chromosomes were normal in all women. The mean ages of the case and control groups were $33.5 \pm 5.6$ and $34.4 \pm 5.3$ years, respectively. The two groups were similar in terms of age $(\mathrm{p}=0.224)$. There were statistically significant differences between the groups in

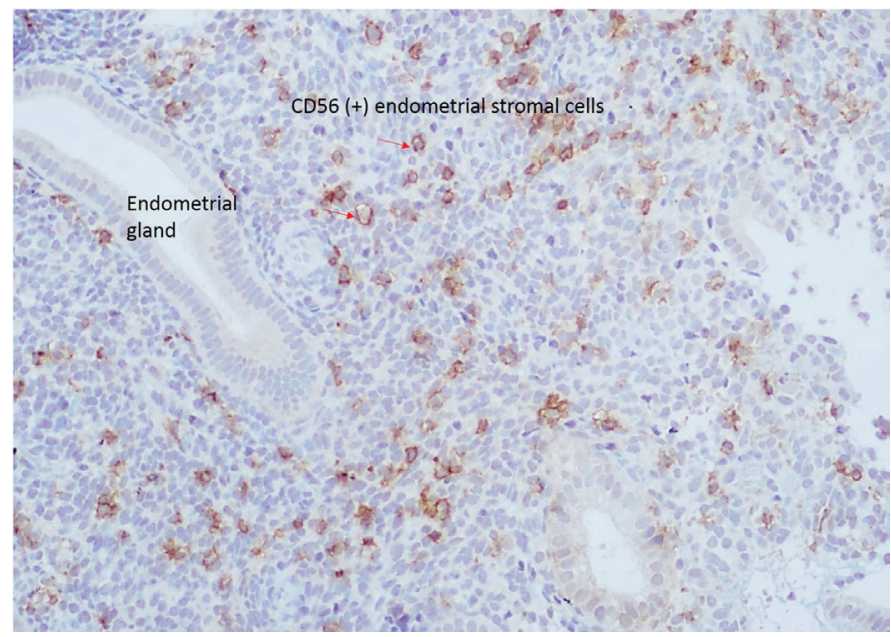

Figure 1. CD56+ cells were shown in the endometrial tissue 
terms of the number of deliveries $(\mathrm{p}<0.001)$ and miscarriages $(\mathrm{p}<0.001)$ (Table 1). The mean number of uNK was $10.5 \pm 10.5$ cells $/ \mathrm{mm}^{2}$ in the case group and $19.2 \pm 11.2$ cells $/ \mathrm{mm}^{2}$ in the control group. There was a statistically significant difference between the two groups in terms of uterine NK ( $p=0.003)$ (Table 1). There was a significant positive correlation between the number of uNK cells and the number of miscarriages $(\mathrm{r}=0.430) \quad(\mathrm{p}=0.002)$. There was also a significant positive correlation between the number of uNKs and the number of live birth $(r=0.463)(p=0.001)$. Correlation coefficients of parity, live birth, miscarriages, and uNK of the patient group are shown in Table 2.

\section{Discussion}

The endometrial leukocyte population consists of T-cells, macrophages, and natural killer cells. T-cells constitute $45 \%$ of leukocytes in the proliferative phase. Although their numbers remain constant throughout the cycle, their rate in proliferative phase is higher compared with other types of leukocytes. The most important leukocyte population in the endometrium comprises uNK cells. These lymphocytes contain the NK cell surface antigen CD56. During the implantation, large granular lymphocytes constitute $70-80 \%$ of the leukocyte population, and if conception occurs, their number increases more. UNK cells are particularly abundant in the uterus at the time of implantation and are in close contact with placental trophoblast cells. UNK cells have a major role in both implantation and the development of the placenta and vascularization. It limits the trophoblast invasion to decidua. In the absence of implantation,

Table 1. Patient demographics and comparison of the number of endometrial CD56+ NK between groups

\begin{tabular}{|l|l|l|l|}
\hline Age (years) & $\begin{array}{l}\text { Implantation } \\
\text { failure }(\mathrm{n}=25)\end{array}$ & $\begin{array}{l}\text { Controls } \\
(\mathrm{n}=25)\end{array}$ & $\mathrm{p}$ \\
\hline No. of deliveries & $33.5 \pm 5.6$ & $34.4 \pm 5.3$ & 0.224 \\
\hline No. of miscarriages & 0 & $2(1-7)$ & $<0.001$ \\
\hline uNK & $10.5 \pm 10.5$ & $2.0(1-3)$ & $<0.001$ \\
\hline
\end{tabular}

uNK: Uterine natural killer
uNK cells undergo apoptosis and are therefore thought to play a role in the initiation of menstrual bleeding. UNK cells also secrete several growth factors involved in angiogenesis, such as VEGF, placental growth factor, and angiopoietin-2.

Giuliani et al. ${ }^{(6)}$ found that the number of endometrial CD56+ cells was not significantly different in women with recurrent pregnancy loss. By contrast, Quenby et al. ${ }^{(7)}$ demonstrated that the mean count of uNK cells was significantly higher in women with recurrent pregnancy loss than women with had a live birth history. Clifford et al. ${ }^{(8)}$ also described increased expression of uNK in 29 women with recurrent pregnancy loss. Similarly, in the current study, there was a positive correlation between the number of miscarriages and the amount of endometrial CD56+ cells. There was also a positive correlation between the number of live births and the number of endometrial CD56+ cells. Different etiologies except for reduced uNK, such as chromosomal abnormalities, could be a reason for miscarriage. Sacks and Finkelstein ${ }^{(9)}$ found that uNK numbers increased dramatically from about $5 \%$ of stromal cells in the follicular and early luteal phases of the menstrual cycle to 30-40\% of stromal cells in the mid and late luteal phases when implantation occurred. Gaynor and Colucci(10) indicated that uNK numbers increased further to as much as $70 \%$ of stromal cells if implantation occurred. The current study demonstrated that there was a positive correlation between the number of live births and the number of endometrial CD56+ cells, and there was also a significantly reduced density of CD56+ cells in women with recurrent implantation failure. In contrast, Tuckerman et al. ${ }^{(11)}$ found that the high density of CD56+ cells in the endometrium of women with RIF was directly involved in implantation duration. Additionally, Santillan et al. ${ }^{(12)}$ found a higher density of endometrial CD56+ cells in women with RIF than in controls. They suggested that testing for endometrial NK cells might be helpful in women with idiopathic RIF during the luteal phase.

We acknowledge that the small sample size, retrospective nature, and lack of the chromosome analysis of the miscarriage tissues are the main limitations of the study. Increasing the number of patients and including other subgroups of CD 56+ cells to the study may help explain the mechanism.

Table 2. Correlation coefficients of parity, live births, miscarriages, and uNK of the patient group

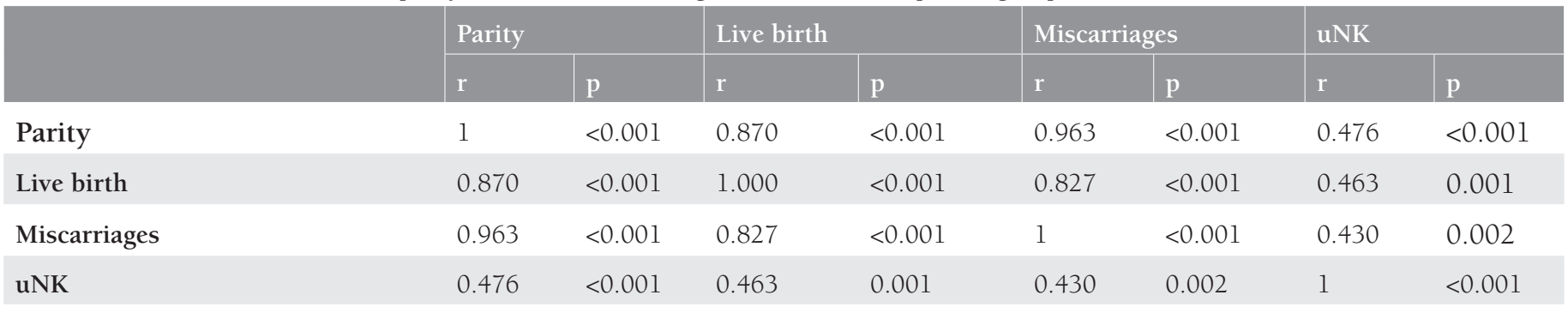

uNK: Uterine natural killer 


\section{Conclusion}

Implantation failure is a multifactorial problem of reproductive medicine. However, the mechanism of this process is still not fully understood. The results of our study suggest that uNKs play a role in the progress of normal pregnancy and reduced uNK cell numbers were associated with implantation failure. We believe that further studies will explain the role of these cells in the etiology.

\section{Ethics}

Ethics Committee Approval: The local ethics committee approved the study (approval no: 20181146).

Informed Consent: The patients were informed orally and in writing.

Peer-review: Externally and internally peer-reviewed.

\section{Authorship Contributions}

Concept: B.G., P.O., M.C.Ç., Design: Y.E.P., R.A., M.C.Ç., Data Collection or Processing: P.O., R.A., Analysis or Interpretation: P.O., R.A., Literature Search: P.O., R.A., Writing: Y.E.P., B.G., R.A., G.B.

Conflict of Interest: The authors report no conflict of interest. Financial Disclosure: Authors have no financial interests about the research.

\section{References}

1. Coughlan C, Ledger W, Wang Q, Liu F, Demirol A, Gurgan T, et al. Recurrent implantation failure: definition and management. Reprod Biomed Online 2014;28:14-38.

2. Van Mourik MS, Macklon NS, Heijnen CJ. Embryonic implantation: cytokines, adhesion molecules, and immune cells in establishing an implantation environment. J Leukoc Biol 2009;85:4-19.
3. Blois S, Tometten M, Kandil J, Hagen E, Klapp BF, Margni RA, et al. Intercellular adhesion molecule-1/LFA-1 cross talk is a proximate mediator capable of disrupting immune integration and tolerance mechanism at the feto-maternal interface in murine pregnancies. J Immunol 2005;174:1820-9.

4. Koopman LA, Kopcow HD, Rybalov B, Boyson JE, Orange JS, Schatz F, et al. Human decidual natural killer cells are a unique NK cell subset with immunomodulatory potential. J Exp Med 2003;198:1201-12.

5. Nagler A, Lanier L, Cwirla S, Phillips J. Comparative studies of human FcRIII-positive and negative natural killer cells. J Immunol 1989;143:3183-91.

6. Giuliani E, Parkin KL, Lessey BA, Young SL, Fazleabas AT. Characterization of uterine NK cells in women with infertility or recurrent pregnancy loss and associated endometriosis. Am J Reprod Immunol 2014;72:262-9.

7. Quenby S, Vince G, Farquharson R, Aplin J. Recurrent miscarriage: a defect in nature's quality control? Hum Reprod 2002;17:1959-63.

8. Clifford K, Flanagan A, Regan L. Endometrial CD56+ natural killer cells in women with recurrent miscarriage: a histomorphometric study. Hum Reprod 1999;14:2727-30.

9. Sacks G, Finkelstein E. Natural killer cells and reproductive success. Am J Reprod Immunol 2020:e13291.

10. Gaynor LM, Colucci F. Uterine Natural Killer Cells: Functional Distinctions and Influence on Pregnancy in Humans and Mice. Front Immunol 2017;8:467.

11. Tuckerman E, Mariee N, Prakash A, Li TC, Laird S. Uterine natural killer cells in peri-implantation endometrium from women with repeated implantation failure after IVF. J Reprod Immunol 2010;87:60-6.

12. Santillán I, Lozano I, Illán J, Verdú V, Coca S, Bajo-Arenas JM, et al. Where and when should natural killer cells be tested in women with repeated implantation failure? J Reprod Immunol 2015;108:142-8. 